\title{
(एiv
}

Polish Society of Hypertension

\section{Guidelines for the Management of Hypertension}

\section{Part 8}

Recommendations of the Polish Society of Hypertension

Guideline editors: Andrzej Tykarski, Krzysztof Narkiewicz, Zbigniew Gaciong, Andrzej Januszewicz, Mieczysław Litwin, Katarzyna Kostka-Jeziorny

Experts: Marcin Adamczak, Ludwina Szczepaniak-Chichel, Marzena Chrostowska, Danuta Czarnecka, Grzegorz Dzida, Krzysztof J. Filipiak, Jerzy Gąsowski, Jerzy Głuszek, Stefan Grajek, Tomasz Grodzicki, Kalina Kawecka-Jaszcz, Beata Wożakowska-Kapłon, Beata Begier-Krasińska, Jacek Manitius, Małgorzata Myśliwiec, Anna Niemirska, Aleksander Prejbisz, Danuta Pupek-Musialik, Grażyna Brzezińska-Rajszys, Katarzyna Stolarz-Skrzypek, Agnieszka Szadkowska, Tomasz Tomasik, Krystyna Widecka, Andrzej Więcek, Adam Windak, Jacek Wolf, Tomasz Zdrojewski, Aleksandra Żurowska 



\section{Secondary hypertension}

\subsection{Introduction}

Secondary hypertension is present in $5-10 \%$ of all hypertensive patients. Appropriate investigations followed by therapy directed at the cause of secondary hypertension may lead to elimination of the underlying cause, resulting in improved control or normalization of BP values with cardiovascular risk reduction.

Simple screening evaluation for secondary forms of hypertension is indicated in all patients with hypertension, based on history, physical examination, and basic laboratory tests.

Clues to the presence of secondary hypertension include:

- severe BP elevation (including paroxysmal hypertension and hypertensive crisis);

- rapidly progressing development of hypertension or worsening of BP control;

- resistant hypertension;

- malignant hypertension;

- poor response to antihypertensive drugs;

- target organ damage that is disproportionate to the duration or severity of hypertension.

Suggestive signs and symptoms and diagnostic procedures to investigate specific forms of secondary hypertension are summarized in Table XXV.

\subsection{Obstructive sleep apnoea}

\subsubsection{Prevalence}

Obstructive sleep apnoea (OSA) is present in a relatively large proportion of hypertensive patients, particularly those with resistant hypertension (up to $85 \%)$. Studies indicate that moderate to severe OSA that requires appropriate management is present in as many as $40-55 \%$ of patients with resistant hypertension. Of note, OSA is also associated with an increased risk of cardiovascular morbidity and mortality.

Due to frequent coexistence, common pathogenetic mechanisms with hypertension, and a limited effect of specific OSA treatment on BP values, some European experts have postulated to consider it a concomitant condition and not a secondary form of hypertension. However, American guidelines (JNC8) list OSA as an important and reversible cause of secondary hypertension.

\subsubsection{History, physical examination, and abnor- malities in routine and additional laboratory tests}

The most common symptoms of OSA are habitual snoring, episodes of apnoea, and excessive daytime somnolescence. Other manifestations of OSA in- clude the following nocturnal symptoms: nycturia, increased motor activity and sweating during the night, awakenings, dyspnoea and/or choking during sleep, difficulties with falling asleep, insomnia, palpitations, mouth and throat dryness, and symptoms of gastroesophageal reflux. In addition to excessive daytime somnolescence, other symptoms during the day include morning tiredness, morning headaches, impaired memory and concentration, decreased libido and impotence, psychoemotional problems, and an increased rate of traffic and workplace accidents. Most studies also indicate that in some hypertensive patients, daytime symptoms of even severe OSA may be modest.

Findings on physical examination mostly include obesity, in particular abdominal obesity. The corrected neck circumference above $48 \mathrm{~cm}$ (actual neck circumference in centimetres plus $4 \mathrm{~cm}$ in hypertensives plus $3 \mathrm{~cm}$ if habitual snoring, and plus $3 \mathrm{~cm}$ if nocturnal choking/dyspnoea) is associated with a significantly increased risk of OSA.

Major underlying causes may include anatomical abnormalities of the upper airways, such as tongue hypertrophy, elongation of the soft palate, tonsil hypertrophy, and impaired nasal patency. Less frequent abnormalities include an abnormal anatomy of the splanchnocranium, for example mandibular hypoplasia and/or retraction.

Most commonly, OSA coexists with metabolic syndrome and thus abnormal glucose and lipid metabolism is often indicated by basic laboratory tests in these patients.

In patients with OSA, ABPM reveals reduced a nocturnal BP fall, non-dipping BP pattern, or even $\mathrm{BP}$ elevation during the night. The presence of OSA may also be indicated by increased morning BP values as detected by HBPM. Holter ECG monitoring in patients with OSA shows intermittent periods of brady-and tachycardia. Echocardiography may show left ventricular hypertrophy (usually of the concentric pattern), left atrial enlargement, mostly diastolic dysfunction, and other abnormalities.

\subsubsection{Investigations}

Investigations for OSA should be considered in hypertensive patients with:

- clinical symptoms suggesting OSA;

- resistant hypertension;

- abdominal obesity and metabolic disturbances (particularly diabetes);

- concomitant coronary artery disease;

- a history of stroke/TIA;

- non-dipping BP pattern;

- nocturnal arrhythmia and/or conduction distur- 


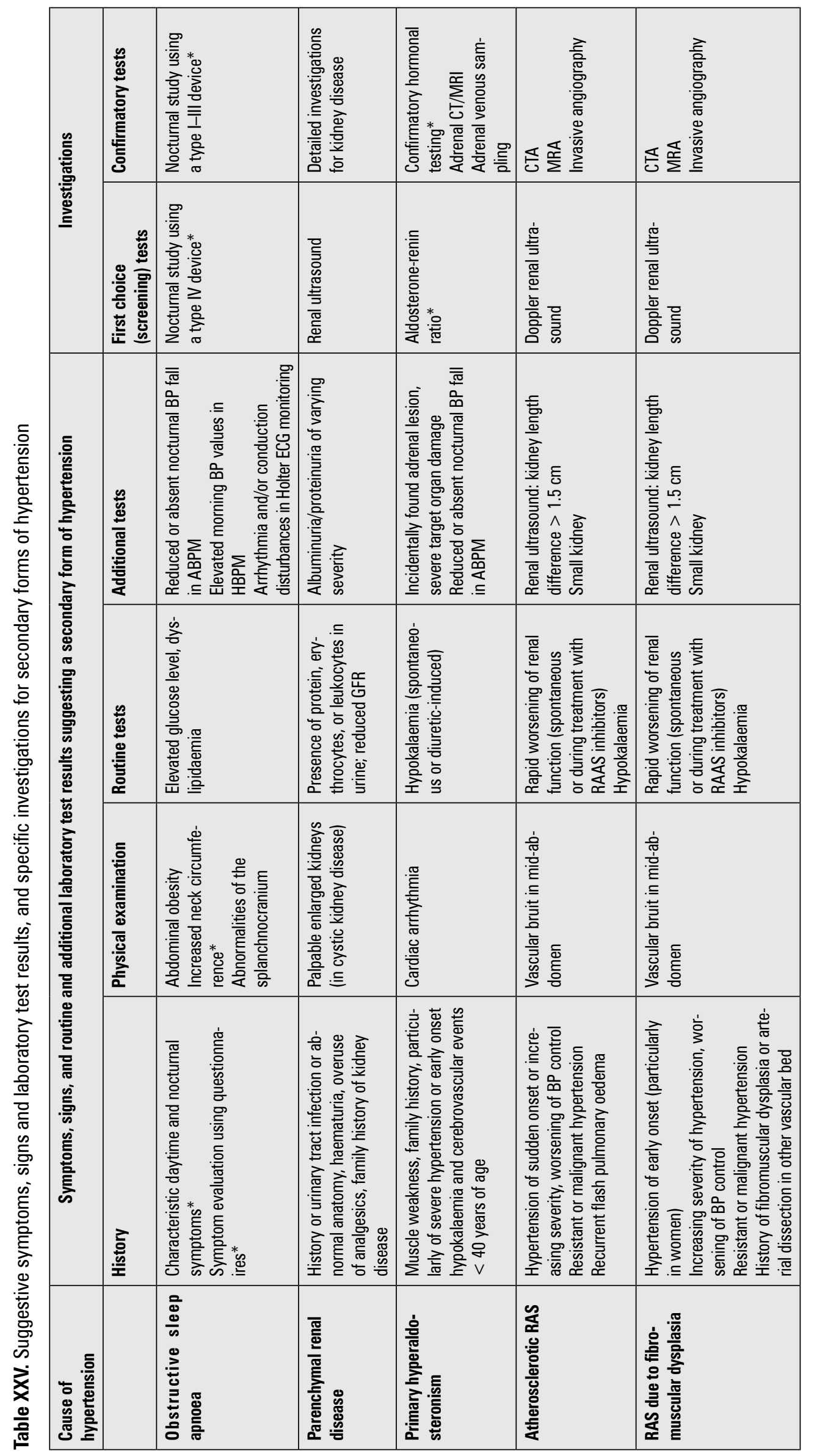




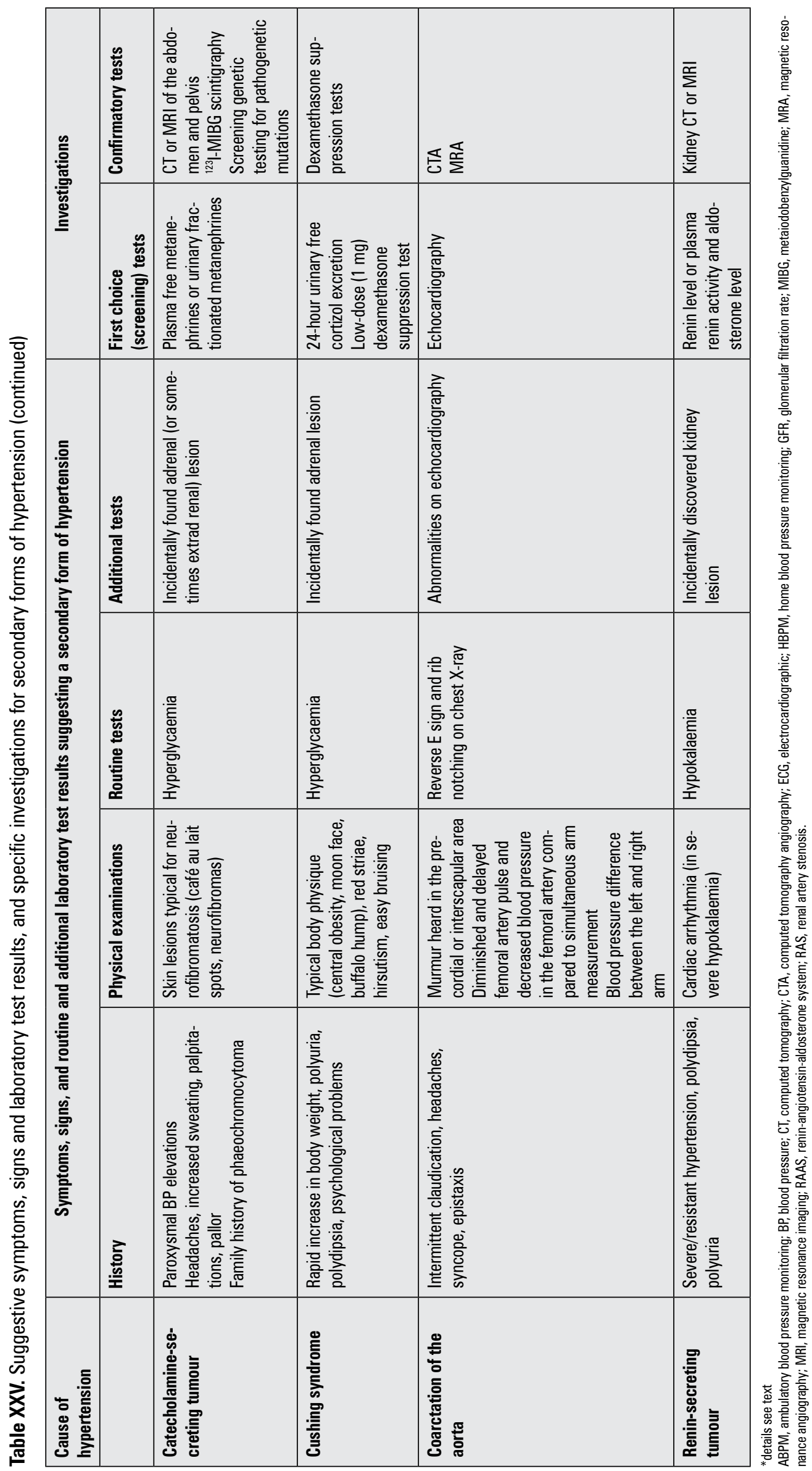

www.nt.viamedica.pl 


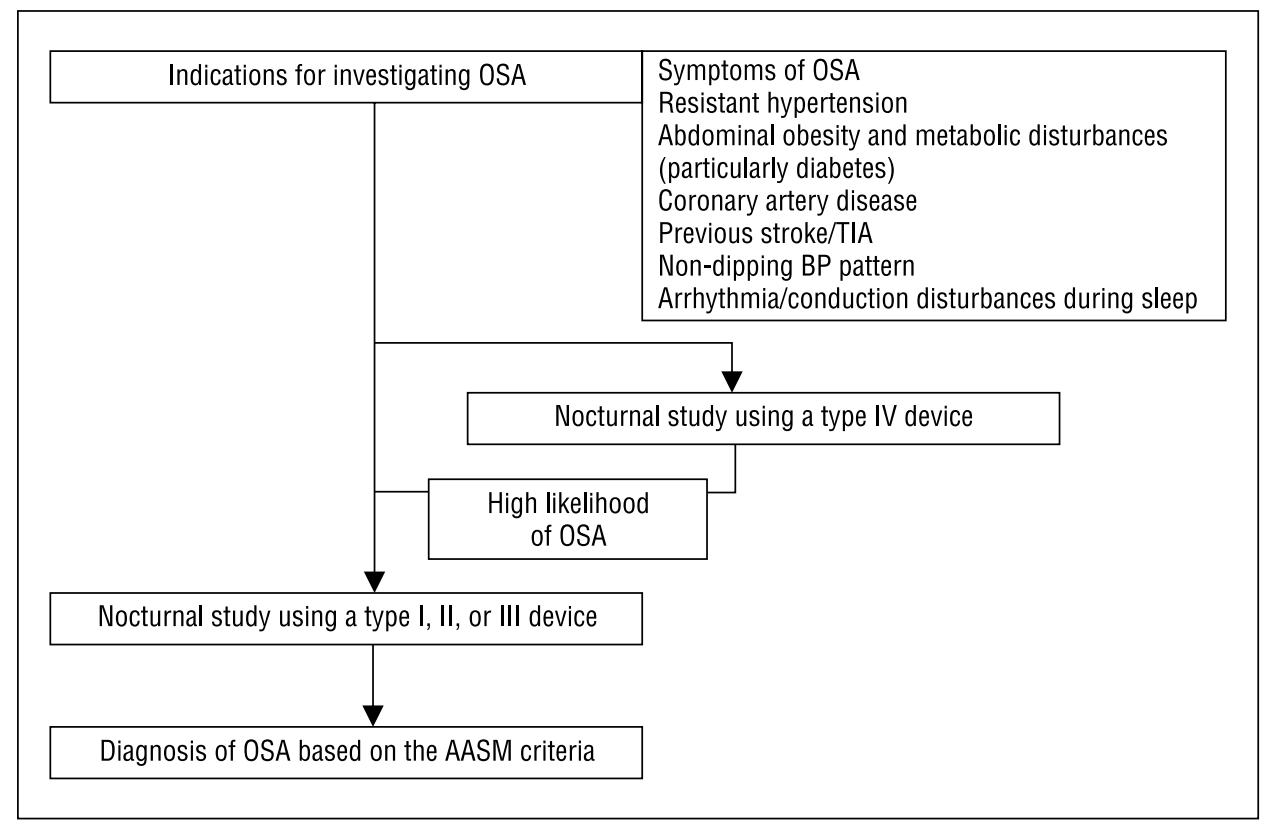

Figure 10. Diagnostic algorithm for obstructive sleep apnoea

AASM, American Academy of Sleep Medicine; BP, blood pressure; OSA, obstructive sleep apnoea; TIA, transient ischemic attack. Type I-IV devices: explanation see text

bances.

Available questionnaires, such as the Epworth Sleepiness Scale and the Berlin Questionnaire, lack specificity to allow excluding OSA. However, they may be helpful in identifying patients at an increased risk of OSA and should be included in the basic evaluation of a hypertensive patient.

Investigations for OSA include 4 types of devices and systems:

I. Complete polysomnography performed in a sleep laboratory.

II. Portable (unsupervised) polysomnography, recording a minimum of 7 channels, including all that are necessary to evaluate the sleep structure and the breathing pattern.

III. Polygraphy, or a limited recording of at 4 least parameters, including respiratory movements of the chest and abdomen, air flow through the upper airway, and oxygen saturation, without evaluation of the sleep structure.

IV. Recording of maximum 2 parameters, e.g., nocturnal pulse oximetry.

Use of different diagnostic devices and the diagnostic algorithm in cases of suspected OSA are summarized in Figure 10.

\subsubsection{Diagnostic criteria}

For a diagnosis of OSA, the criteria A, B, and D or only $\mathrm{C}$ and $\mathrm{D}$ must be fulfilled.
A. At least one of the following:

a. inadvertent falling asleep, excessive daytime somnolescence, ineffective sleep, tiredness, or insomnia;

b. awakenings with the feeling of breathing cessation, dyspnoea or choking;

c. habitual snoring or episodes of apnoea noted by the partner of the patient.

B. Polysomnography findings:

a. at least 5 disordered breathing events per hour of sleep (AHI $\geq 5$ );

b. respiratory muscle activity noted during these episodes.

C. Polysomnography findings:

a. at least 15 disordered breathing events per hour of sleep (AHI $\geq 15)$;

b. respiratory muscle activity noted during these episodes.

D. The above findings are not related to other sleep disturbances, diseases (including neurological disease), or use of medications or other substances.

- Classification of the severity of OSA:

- Mild OSA (AHI $\geq 5$ and $\leq 15$ );

- Moderate OSA (AHI > 15 and $\leq 30)$;

- Severe OSA (AHI > 30).

\subsubsection{Management of obstructive sleep apnoea}

The management of OSA includes the following:

- behavioural methods: 
- body weight reduction (in all patients);

- avoidance of a supine position during sleep or sleeping in a semi-sitting position (in patients with mild or moderate OSA without severe obesity);

- avoidance of alcohol intake (in all patients);

- smoking cessation (in all patients);

- avoidance of sedative-hypnotics and narcotic analgesics (in all patients);

- mandibular advancement splints (simple snoring and mild OSA not responsive to behavioural treatment);

- continuous positive airway pressure (CPAP) therapy (all patients with $\mathrm{AHI}>30$; patients with AHI $>15$ and excessive daytime somnolence [Epworth Sleepiness Scale score $>10$ ] or cardiovascular disease)

- $\quad$ surgery (indications set individually).

Of the above methods, a beneficial effect on the reduction of cardiovascular risk and mortality has been shown only for the CPAP therapy. Published studies also indicate that regular use of CPAP for an appropriately long period of time during the night may be associated with BP lowering, particularly in patients with resistant hypertension.

\subsubsection{Treatment of hypertension in patients with obstructive sleep apnoea}

Limited data are available to develop recommendations regarding antihypertensive therapy in patients with OSA. Some evidence suggests benefits of aldosterone antagonists in terms of not only improvement of BP control but also reduction of the severity of OSA. However, these studies were performed in small groups of patients and further studies are required. Further research is also necessary to determine potential benefits of renal denervation in patients with resistant hypertension and concomitant OSA.

\subsubsection{Care for patients with hypertension and concomitant obstructive sleep apnoea}

The following issues should be evaluated during each visit related to the treatment of hypertension:

- in patients with previously undiagnosed OSA:

- symptoms suggestive for, and the risk of OSA,

— indications for investigations to diagnose OSA;

- in patients with established OSA without previous indications for CPAP therapy:

- compliance regarding behavioural therapy for OSA,

— indications for reassessment of the severity of OSA;
- in patients with established OSA and indications for CPAP therapy:

- compliance regarding behavioural therapy for OSA,

- compliance regarding CPAP therapy, and factors associated with noncompliance with this therapy,

- frequency and duration of CPAP therapy during the night (data retrieved from the device memory).

\subsection{Atherosclerotic renal artery stenosis 8.3.1. Introduction}

Hypertension due to renal artery stenosis (RAS), also known as renovascular hypertension, is a secondary form of hypertension caused by excessive renin production in the ischemic kidney. Significant RAS does not only produce hypertension but also impairs excretory, endocrine, and homeostatic renal function and results in ischemic nephropathy. In some patients, RAS is a cause of end-stage renal disease and the need for renal replacement therapy. Most commonly, RAS is of atherosclerotic origin. The second most common cause of RAS is fibromuscular dysplasia, which is discussed in a separate section of the present document.

\subsubsection{Indications for investigations to diagnose atherosclerotic renal artery stenosis}

Investigations to diagnose atherosclerotic renal artery stenosis should be considered primarily in patients with:

- hypertension that is:

- severe,

- resistant,

- malignant (accelerated);

- episodes of unexplained flash pulmonary oedema (Pickering syndrome) and/or unexplained congestive heart failure;

- unexplained renal failure (including patients in whom renal replacement therapy is initiated);

- new-onset azotaemia or worsening of renal function following administration of a RAAS inhibitor;

- hypokalaemia, particularly in patients treated with diuretics;

- an abdominal bruit;

- difference in kidney length $>1.5 \mathrm{~cm}$ or a small kidney.

Atherosclerotic RAS should also be suspected in hypertensive patients with atherosclerosis in other vascular beds, including coronary arteries. The rates of atherosclerotic RAS correlate with the severity of atherosclerosis in other vascular beds. 


\subsubsection{Diagnostic methods for renal artery stenosis}

\subsubsection{Doppler renal ultrasonography}

Doppler renal ultrasonography is recommended as the first-line noninvasive diagnostic test in patients with suspected RAS. It allows evaluation of the extraand intrarenal arteries, localization of the stenosis, and assessment of its aetiology.

In patients with a suspicion of RAS based on Doppler renal ultrasonography and clinical indications for revascularization, computed tomography angiography (CTA), magnetic resonance angiography (MRA), or invasive renal angiography should be performed before the revascularization procedure.

Renal CTA or MRA should be also performed in case of normal Doppler renal ultrasonography findings in patients with a significant clinical suspicion of RAS.

Doppler renal ultrasonography allows long-term follow-up of patients after correction of RAS and evaluation of disease progression in medically treated patients. Follow-up examinations in revascularized patients should be performed immediately after the revascularization procedure and 6-12 months afterwards. Follow-up examinations to evaluate progression of borderline lesions treated medically should be performed annually. In these patient groups, urgent Doppler renal ultrasound reevaluation should be performed in case of acute worsening of $\mathrm{BP}$ control and/or renal function.

\subsubsection{Computed tomography angiography}

Computed tomography angiography is indicated to confirm the diagnosis of RAS (in patients with normal or moderately impaired renal function, defined as $\mathrm{eGFR}>30 \mathrm{~mL} / \mathrm{min}$ ).

Normal CTA findings exclude a hemodynamically significant stenosis of the main renal artery. Advantages over MRI include better spatial resolution and fewer artifacts in patients with renal stents. CTA should include urographic phase images in patients with a small kidney or a critical RAS.

Disadvantages of CTA include the risk of adverse effects related to intravenous administration of an iodine contrast agent and the effects of ionizing radiation absorbed by the patients. Another disadvantage of CTA is a limited ability to evaluate the significance of stenoses in accessory renal arteries and intrarenal arterial branches.

\subsubsection{Magnetic resonance angiography}

Magnetic resonance angiography is indicated to confirm the diagnosis of RAS. The most effective imaging sequence is three-dimensional gradient echo (3D GRE) following intravenous administration of a contrast agent. Evaluation should include both primary images and multiplanar reconstructions. Contrast-enhanced MRA allows excluding a hemodynamically significant stenosis of the main renal artery.

Magnetic resonance angiography is also useful for imaging of kidney transplant vessels. Nephrotoxicity of paramagnetic contrast agents in doses used for MRI is low and occurs infrequently but a possibility of nephrogenic systemic fibrosis in patients with renal dysfunction should be taken into consideration. In patient with significant renal dysfunction, MRA may be performed without contrast enhancement (using techniques such as true fast imaging with steady state precession [true-FISP], time-of-flight [TOF] angiography, and phase contrast $[\mathrm{PC}]$ imaging), with somewhat lower image quality compared to contrast-enhanced images.

Disadvantages of MRA include somewhat lower spatial resolution, a tendency to overestimate the degree of vessel stenosis, unreliable evaluation of the patency of some stents due to artifacts, and poor ability to evaluate small arteries (with a diameter of $<2 \mathrm{~mm}$ ), including accessory renal arteries and intrarenal arterial branches.

\subsubsection{Invasive renal angiography}

Invasive renal angiography is performed to image the renal artery and its branches. It involves introduction of a pigtail catheter to the aorta at the level of renal arteries and injecting an iodine contrast agent. This method allows very good visualization of both the main renal artery and accessory renal arteries, and particularly their origin from the aorta. Selective renal angiography using catheters with appropriately curved tips is also recommended.

The indication for invasive renal angiography is the presence of clinical findings suggesting significant RAS, if the diagnosis cannot be definitively established based on noninvasive testing only.

Disadvantages of this method include an invasive nature of the procedure, exposure to ionizing radiation, and use of a potentially nephrotoxic contrast agent.

If the aetiology of the lesion is unclear, conventional angiography may be supplemented with intravascular ultrasound (IVUS).

In the recent years, it has been suggested to use translesional pressure gradient measurements using a special guidewire to identify hemodynamically significant RAS. The ratio of the mean pressure distal to the stenosis to the mean aortic pressure at basal conditions below 0.9 was associated with increased renin production. This ratio correlates with papaverine-induced systolic pressure gradient of more than 
Table XXVI. Indications for revascularization of atherosclerotic renal artery stenosis (RAS)

\begin{tabular}{|l|}
\hline Angioplasty may be considered (rather with stent implantation) in symptomatic RAS $>60 \%$ secondary to atherosclerosis \\
\hline If angioplasty is indicated, stenting is recommended to treat ostial RAS of atherosclerotic aetiology \\
\hline Interventional RAS treatment may be considered in patients with renal dysfunction \\
\hline Balloon angioplasty with or without stenting may be considered in patients with RAS and recurrent congestive heart failure of undetermined aetio- \\
logy, or with flash pulmonary oedema with preserved left ventricular ejection fraction \\
\hline $\begin{array}{l}\text { Surgical revascularization may be considered in patients undergoing aortic repair surgery, patient with complex renal artery anatomy, and following } \\
\text { failure of interventional treatment }\end{array}$ \\
\hline
\end{tabular}

$21 \mathrm{~mm} \mathrm{Hg}$ under the conditions of maximal hyperaemia. Dopamine-induced pressure gradient above $20 \mathrm{~mm} \mathrm{Hg}$ was associated with a favourable response to renal artery stenting.

Use of invasive renal angiography is limited to imaging before angioplasty and quantitative evaluation of the stenosis. This method may also be considered in patients with a significant clinical suspicion of RAS who undergo other invasive angiographic imaging (e.g., coronary angiography).

\subsubsection{Other investigations}

Captopril renal scintigraphy, renal vein catheterization, measurements of plasma renin activity, and the captopril challenge test are not recommended as screening tests for the diagnosis of RAS.

\subsubsection{Management of atherosclerotic renal artery stenosis}

Until now, no randomized study showed a significant effect of interventional treatment on the course of hypertension. The decision to implant a stent into a renal artery with an atherosclerotic stenosis should be based on multiple additional clinical factors and laboratory parameters. The arbitral stenosis threshold at $60 \%$ is worryingly low and may result in too hasty consideration of the intervention. Taking into account often erroneous estimation of the stenosis degree by angiography, and the effect of additional clinical and nephrological parameters on the decision to proceed with the intervention, patient selection and stent implantation should be performed in experienced hypertension units.

In a large randomized study published in 2013 (CORAL), it was found that revascularization in patients with atherosclerotic RAS was not associated with additional benefits in regard to a reduction in the mortality rate due to cardiovascular or renal events, cardiovascular event rate reduction, improvement of renal function, and a reduced rate of renal events compared to medically treated patients. In both groups, a significant BP - lowering effect was seen, obtained by intensification of the drug treatment using a combination of $\mathrm{ARB}+$ calcium antagonist + thiazide diuretic (mean SBP reduction throughout the study was $16-17 \mathrm{~mm} \mathrm{Hg}$ ). SBP lowering was more pronounced in the revascularization group (between-group difference of $2.3 \mathrm{~mm} \mathrm{Hg}$ ).

Indications for revascularization of atherosclerotic RAS are shown in Table XXVI.

\subsubsection{Treatment of hypertension in patients with atherosclerotic renal artery stenosis}

In patients with unilateral RAS, ACEI and calcium antagonists are effective in the treatment of hypertension and may decrease progression of nephropathy. Even in unilateral RAS, treatment with ACEI or ARB requires caution and monitoring of renal function parameters. A significant decrease in eGFR (by $\geq 30 \%$ ) or an increase in plasma creatinine level (by $>0.5 \mathrm{mg} / \mathrm{dL}$ ) may indicate the need to consider revascularization. ACEI and ARB are contraindicated in bilateral RAS and RAS in the single kidney.

Available evidence indicates that thiazide/thiazide-like diuretics, ARB, and beta-blockers are also effective in lowering BP to target values in patients with RAS.

The CORAL study showed that a combination of an ARB, a calcium antagonist, and a thiazide diuretic is effective antihypertensive drug therapy in patients with atherosclerotic RAS and difficult-to-control hypertension.

All patients with atherosclerotic RAS should be treated in accordance with the guidelines on cardiovascular disease prevention.

\subsubsection{Care for patients with hypertension and concomitant atherosclerotic renal artery stenosis}

In patients with end-stage renal disease, life expectancy is the shortest among patients with RAS. However, life expectancy is also significantly reduced in RAS patients without end-stage renal disease. Two-year mortality in patients with baseline serum creatinine concentrations before revascularization below $1.2 \mathrm{mg} / \mathrm{dL}$, 
$1.2-2.5 \mathrm{mg} / \mathrm{dL}$, and above $2.5 \mathrm{mg} / \mathrm{dL}$ was $5 \%, 11 \%$, and $70 \%$, respectively. More than $80 \%$ patients die due to cardiovascular disease. Thus, patients with atherosclerotic RAS should be considered a very high cardiovascular risk population.

\subsection{Renal artery stenosis due to fibromuscular dysplasia}

Fibromuscular dysplasia (FMD) most commonly involves renal arteries and leads to the development of hypertension. Carotid arteries are the second most common location of FMD. FMD may be present in virtually all vascular beds, and is often concomitantly present in several areas in the vascular system. In a French registry of patients with FMD in the renal arteries, the rate of FMD in other vascular beds was $25 \%$ in the carotid arteries, $9 \%$ in the lower limb arteries, and $31 \%$ in other abdominal arteries. The arterial wall affected by FMD is prone to dissection and the development of aneurysms. Dysplastic changes located in the carotid and vertebral arteries may coexist with cerebral aneurysms. Renal artery dissection may have serious clinical consequences, leading to an acute development of severe, resistant, or malignant hypertension, loss of kidney function, and renal infarction. In patients with FMD, dissection may also involve other arteries, including carotid and coronary arteries.

\subsubsection{Definition of fibromuscular dysplasia}

Fibromuscular dysplasia is an idiopathic, segmental, non-atherosclerotic, and non-inflammatory vascular disease that leads to the development of stenoses in small- and medium-sized arteries.

\subsubsection{Indications for investigations to diagnose fibromuscular dysplasia}

The indications for investigating a possibility of RAS due to FMD in hypertensive patients include:

- age below 30 years, particularly in women;

- grade 3 hypertension ( $\geq 180$ and/or $110 \mathrm{~mm} \mathrm{Hg}$ ), accelerated or malignant hypertension;

- resistant hypertension;

- small kidney without a previous history of uropathy;

- abdominal bruit without evidence of atherosclerosis;

- established FMD in at least one other vascular bed.

Indications for investigations to diagnose FMD in the neck and head arteries and other vascular beds:

- investigations for FMD in the craniocervical arteries should be considered in patients with a history of retinal or cerebral ischemic events, intracranial aneurysms, subarachnoid haemorrhage, craniocervical arterial dissection, or pulsatile tinnitus;

- in patients with FMD in the renal arteries, investigations for FMD in the craniocervical arteries should be considered if identification of such lesions is likely to affect future patient management;

- in patients with FMD within renal and/or craniocervical arteries, investigations for FMD lesions in other vascular beds (which are less frequent) should be considered in patients with suggestive symptoms or past medical history;

- investigations for FMD are also indicated in patients with spontaneous coronary artery dissection, particularly with the presence of hypertension or other suggestive symptoms;

- in patients with FMD in the craniocervical arteries, investigations for intracranial aneurysms are indicated if identification of such a lesion is likely to affect future patient management.

In patients with FMD, it is recommended to take family history regarding early development of hypertension and the occurrence of intracranial dissection, aneurysm or bleeding in first-degree relatives. In case of any positive family history, the patient may inform his or her relatives about the possibility of hereditary FMD.

\subsubsection{Investigations for renal artery stenosis due to fibromuscular dysplasia}

- Doppler renal ultrasonography:

- is a screening test to detect most cases of RAS;

- a positive result requires confirmation by other diagnostic modality, as does a negative result in a patient with a significant clinical suspicion of RAS.

- Magnetic resonance or computed tomography angiography (preferred);

- is recommended to confirm FMD in the renal arteries;

- is recommended as a screening (first-line) test if Doppler renal ultrasonography may be expected to be suboptimal (obese patients, withholding breath difficult or impossible, low echogenicity, little ultrasonographer experience);

- is recommended as a screening (first-line) test if the suspicion of FMD is very strong and/or the diagnosis has significant clinical consequences (very young age, malignant or complicated hypertension, complications in other vascular beds, increased creatinine level). 
- Invasive renal digital subtraction angiography is recommended in patients with FMD confirmed by CTA or MRA if revascularization is clinically indicated:

- in patients with a high degree of suspicion of RAS due to FMD;

- in patients with uncertain diagnosis based on non-invasive studies.

\subsubsection{Management of renal artery stenosis due to fibromuscular dysplasia}

- In hypertensive patients with RAS due to FMD, revascularization is indicated:

- in patients with a recent-onset hypertension, as the treatment of choice to normalize BP;

- in patients in whom drug treatment is unsuccessful (due to drug resistance or intolerance);

- in patients with renal failure or renal function worsening, particularly after administration of an ACEI or ARB;

— in patients with a smaller kidney supplied by a significantly stenosed artery.

- Renal angioplasty is the treatment of choice for significant RAS due to FMD. Stenting is not recommended, except for periprocedural dissection.

- Surgical treatment of significant RAS due to FMD should be considered in patients with:

- stenosis associated with a complex aneurysm;

- recurrent stenosis after two unsuccessful angioplasty procedures;

- a lesion involving renal artery bifurcation and its branches.

- In hypertensive patients with RAS due to FMD in whom revascularization is not indicated, appropriate follow-up is recommended, including:

- clinical follow-up (monthly BP evaluation until target values are obtained, followed by further regular follow-up);

- biochemical follow-up (yearly measurements of creatinine level);

— imaging (yearly evaluation of kidney length by ultrasonography).

- In patients after revascularization for RAS due to FMD, recommendations include:

- evaluation of BP and eGFR at one month after the procedure;

- renal imaging at 6 months after the procedure or earlier in case of BP elevation or creatinine level rise.

- Patients with FMD should be strongly urged to stop smoking. They should be engaged in smoking cessation programs using all available agents recommended in the respective guidelines.

\subsection{Primary hyperaldosteronism 8.5.1. Definition and prevalence}

Primary hyperaldosteronism (PHA) is defined as a hormonally mediated form of hypertension caused by autonomous aldosterone production. Using this definition, PHA is diagnosed by showing that aldosterone level is unaffected by factors that affect its production in physiological conditions.

Primary hyperaldosteronism is not a pathogenetically uniform condition, and several forms of PHA are distinguished depending on the hormonal profile and the management approach:

- bilateral adrenal hyperplasia;

- adrenal cortex adenoma;

- familial hyperaldosteronism type I;

- familial hyperaldosteronism type II;

- familial hyperaldosteronism type III;

- aldosterone-producing adrenal carcinoma;

- ectopic aldosterone production (by neoplastic tissue).

The prevalence of PHA in hypertensive patients depends on BP values. In the general hypertensive population, $\mathrm{PHA}$ is present in up to $7 \%$ of patients (depending on the definition of PHA), while the prevalence of PHA in patients with resistant hypertension has been estimated at 6-23\%.

\subsubsection{Clinical presentation}

Clinical symptoms of PHA result from excessive autonomous aldosterone production. An increased aldosterone level results in elevated urinary potassium excretion and reduced plasma potassium level, leading to hypokalaemia which is the cause of most PHA symptoms. Reduced potassium level induces muscle cell polarization disturbances, manifesting clinically as muscle weakness. Loss of the urine concentrating function of the kidney, resulting from hypokalaemic nephropathy, may lead to polyuria and polydypsia. In some patients, potassium levels may be in the normal range, and $\mathrm{BP}$ elevation may be modest.

It has been suspected that by inducing hypokalaemia and directly affecting cardiomyocytes and the cardiac conduction system, increased aldosterone level may contribute to cardiac arrhythmia and conduction disturbances. In patients with PHA, hypertensive target organ damage is more severe compared to patients with essential hypertension. ABPM in PHA patients may reveal elevated BP during the night with a reduced nocturnal BP fall, or even no nocturnal BP fall and BP rise during the night. Primary hyperaldosteronism may also coexist with OSA, particularly in patients with metabolic syndrome. 


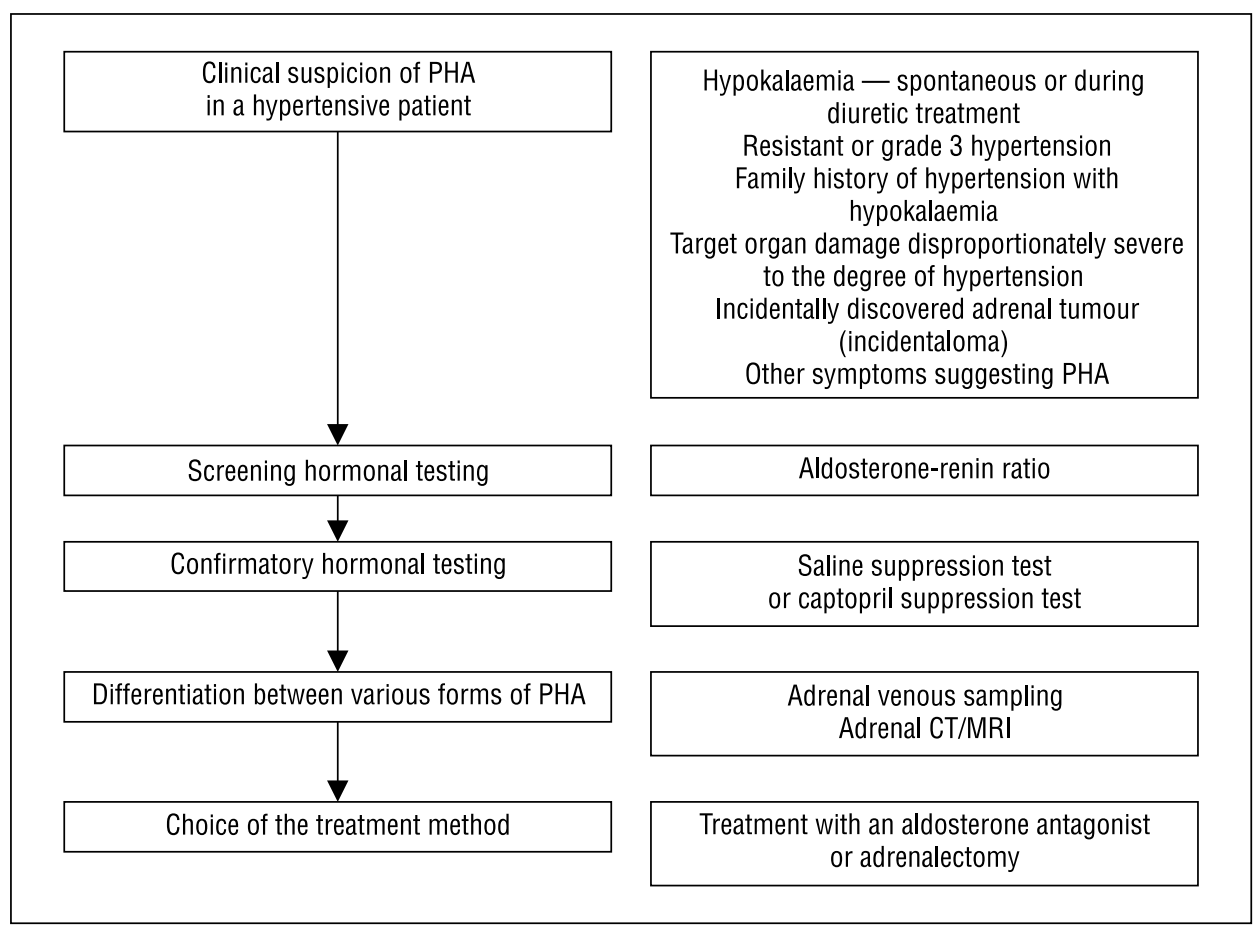

Figure 11. Diagnostic algorithm for primary hyperaldosteronism

CT, computed tomography; MRI, magnetic resonance imaging; PHA, primary hyperaldosteronism

Indications for investigations for PHA are summarized in Figure 11.

\subsubsection{Screening for primary hyperaldosteronism}

The primary screening test for PHA is evaluation of the aldosterone-to-renin ratio (ARR). When evaluating and interpreting ARR, the following should be taken into consideration:

- in patients with hypokalaemia, potassium level should be brought to normal values by adequate supplementation, and dietary sodium intake should also be controlled (normal sodium diet);

- antihypertensive drug therapy should be appropriately modified:

- drugs that significantly affect ARR should be withdrawn 4 weeks before testing, including spironolactone, eplerenone, triamterene, amiloride, thiazide/thiazide-like diuretics, and loop diuretics,

- if ARR is nondiagnostic and hypertension may be adequately controlled using drugs that do not affect ARR (see below), the following medications should be withdrawn 2 weeks before testing: beta-blockers, central alpha $a_{2}$-agonists (clonidine, methyldopa), nonsteroidal antinflammatory drugs (false-positive ARR), and ACEI, ARB, renin inhibitors, and dihydropyridine calcium antagonists (false-negative ARR),
- drugs that have the least effect on ARR should be used to control hypertension, including verapamil, hydralazine, doxazosin, prazosin, and terazosin,

- in some situations, due to high BP values and concomitant conditions, appropriate modification of antihypertensive drug therapy is not possible and may be even associated with an increased cardiovascular risk; in these circumstances, the effect of drug therapy used in the patient should be taken into account;

- blood sampling for ARR should be performed in a sitting position between 9 and $10 \mathrm{AM}$, with the patient remaining upright (sitting, standing, walking) for 2-4 hours before blood collection, and the collected blood samples should be handled appropriately as agreed with the laboratory;

- due to the fact that interpretation of ARR is based on values considered abnormal in previous research studies and not reference ranges for the assays used in the laboratories, ARR should be determined in laboratories in which the assays for aldosterone and plasma renin activity or renin level were validated against the laboratories that have appropriate experience in the diagnosis of PHA;

- most commonly, the ARR value suggesting PHA is defined as:

- above 30 (aldosterone level in ng/dL and plasma renin activity in $\mathrm{ng} / \mathrm{mL} / \mathrm{h}$ ); or 
- above 830 (aldosterone level in pmol/L and plasma renin activity in $\mathrm{ng} / \mathrm{mL} / \mathrm{h}$ ),

- for an elevated ARR to suggest PHA, plasma aldosterone level must be at least moderately increased (e.g., $>15 \mathrm{ng} / \mathrm{dL}$ or $>10 \mathrm{ng} / \mathrm{dL}$ ),

- ARR is also much affected by the lower limit of detection of plasma renin activity by a given assay, which may be different for different assays and laboratories (plasma renin activity value used for calculating ARR should not be lower than $0.2 \mathrm{ng} / \mathrm{mL} / \mathrm{min}$ ),

- in the recent years, commercial assays to determine plasma renin level have been introduced; ARR conversion coefficient for renin level should be determined separately for each assay;

- other factors that may affect ARR value interpretation should also be taken into account, including age (low-renin essential hypertension in the elderly), creatinine level, concomitant conditions, difficult blood sampling, and use of hormonal drugs (oestrogen-containing preparations are associated with false-positive ARR values).

\subsubsection{Confirmatory tests}

The diagnosis of PHA is confirmed by establishing no effect of factors that normally decrease plasma aldosterone level or 24-hour urinary aldosterone excretion. Biochemical tests used to confirm the diagnosis of PHA include:

- oral salt loading test;

- saline suppression test;

- fludrocortisone suppression test;

- captopril suppression test.

When performing these tests, the same principles apply as described above for the screening tests (normalization of potassium level, normal sodium diet, appropriate modification of antihypertensive drug therapy). In Poland, the two tests that are currently most commonly used are the saline suppression test and the captopril suppression test:

- saline suppression test involves intravenous infusion of 2 litres of normal saline $(0.9 \% \mathrm{NaCl})$ during 4 hours in a patient remaining in a semi -recumbent position. Plasma aldosterone level below $5 \mathrm{ng} / \mathrm{dL}$ at the end of the test indicates a low likelihood of PHA, and the level above $10 \mathrm{ng} / \mathrm{dL}$ indicates very likely PHA. Values in the range of 5-10 ng/dL should be interpreted individually. Due to a risk of complications such as worsening of BP control or exacerbation of heart failure, caution is necessary during this test;
- captopril suppression test involves measuring plasma aldosterone level (along with plasma renin activity or renin level) at baseline and 2 hours after administration of $25-50 \mathrm{mg}$ of captopril. Normally, aldosterone level is reduced in these circumstances by more than $30 \%$, and in patients with PHA it remains elevated, and plasma renin activity or renin level remains unsuppressed. The test is performed after assuming an upright position for more than one hour. During the test, the patient remains in the sitting position and $\mathrm{BP}$ should be evaluated frequently. In patients with suspected familial PHA type I, possible investigations include genetic testing, urinary excretion of 18-oxocortisol and 18-hydroxycortisol, and the dexamethasone suppression test.

\subsubsection{Differentiation between various forms of primary hyperaldosteronism}

After the diagnosis of PHA has been established based on clinical symptoms and biochemical test findings, it is necessary to assess the nature and location of adrenal lesions. Various forms of PHA, in particular bilateral adrenal hyperplasia and adrenal adenoma, should also be differentiated.

\subsubsection{Computed tomography}

Computed tomography (CT) is currently the standard method to evaluate adrenal lesions. Its sensitivity for detecting adrenal tumours exceeds $90 \%$. CT allows assessment of the morphology of detected adrenal tumours and identification of adrenal hyperplasia (anatomic evaluation). Varying reference ranges for normal thickness of the adrenals and their crura have been reported in the literature: an abnormal finding is segmental thickening of a single crux above $5-7 \mathrm{~mm}$ or the whole gland above $7-10 \mathrm{~mm}$.

\subsubsection{Magnetic resonance}

Magnetic resonance imaging (MRI) has a similar sensitivity for detecting adrenal tumours compared to CT (> 90\%). Evaluation of the nature of detected lesions is based on the application of chemical shift for the detection of lipids in adrenal adenomas. MRI is a second-line method to evaluate adrenal tumours that could not be adequately characterized by CT.

\subsubsection{Adrenal scintigraphy}

Adrenal scintigraphy is of little usefulness in differentiating between PHA forms. A new technique is positron emission tomography (PET)-CT using 11C-methomidate. Initial data suggest a potential utility of this method for distinguishing between various forms of PHA. 


\subsubsection{Adrenal venous sampling}

Adrenal venous sampling (AVS) is the method of choice for differentiating between various forms of PHA (Figure 11). It should be performed only in adequately experienced centres. The success of this procedure in such centres, based on the proportion of diagnostically useful results, is more than $90 \%$. In some patients, the finding of lateralized aldosterone secretion by AVS allows the diagnosis of adrenal adenoma smaller than $1 \mathrm{~cm}$ which is not detectable by CT. During AVS, blood samples are collected from both adrenal veins and from the vena cava inferior below the entry of renal veins, and aldosterone and cortisol levels are measured in the collected samples. Appropriate blood collection is confirmed by a higher cortisol level in the samples from the adrenal veins compared to the inferior vena cava sample (selectivity index). This should be done intraprocedurally, allowing further blood sampling in case the previous samples were not drawn from the adrenal veins. Interpretation of the aldosterone level requires determination of the aldosterone to cortisol level ratio in a given sample. Currently, it is generally accepted that lateralized aldosterone secretion is indicated by this ratio of at least 4:1. The test may be performed during ACTH infusion or without administration of ACTH.

Adrenal venous sampling should be performed in patients with the diagnosis of PHA in whom adrenalectomy is considered, except for patients:

- below 35 years of age, with significantly elevated aldosterone level, spontaneous hypokalaemia and clear CT/MRI findings of a unilateral adenoma (with the additional lesion size criterion of $>10 \mathrm{~mm}$ according to some authors) and a normal contralateral adrenal gland (in some centres, however, AVS is performed in all patients regardless of their age and imaging study findings);

- with an unacceptably high risk associated with adrenalectomy (e.g. elderly patients with significant comorbidities);

- with a suspicion of adrenal carcinoma;

- with the diagnosis of familial PHA type I or III;

- with 11C-methomidate PET-CT findings indicating a unilateral lesion, if it is not possible to perform AVS;

- with severe PHA, including high aldosterone level and hypokalaemia, if CT shows a unilateral lesion, familial PHA type I or III has been excluded, and it is not possible to perform AVS.

\subsubsection{Management of primary hyperaldosteronism}

In documented unilateral PHA due to an aldosterone-producing adenoma or unilateral adrenal hy- perplasia, the treatment of choice is unilateral laparoscopic adrenalectomy, while patients with bilateral adrenal disease (idiopathic adrenal hyperplasia or bilateral adenomas) should be treated with aldosterone antagonists. Glucocorticoid-remediable aldosteronism should be treated with low doses of a long-acting glucocorticosteroid, e.g., dexamethasone.

In patients with bilateral adrenal disease and those with unilateral PHA who did not undergo adrenalectomy for various reasons, aldosterone antagonists are indicated. The initial spironolactone dose should be $12.5-25 \mathrm{mg}$ once daily. The lowest effective dose should be determined by a gradual dose increase to $100 \mathrm{mg}$ per day or more. To avoid high spironolactone doses, which may result in adverse effects, a thiazide diuretic, amiloride, or triamterene may be added. Eplerenone is a newer, selective mineralocorticoid receptor antagonist characterized by a weaker antiandrogenic effect and a weaker agonist effect on the progesterone receptor, and thus it is associated with a lower rate of adverse effects. The strength of its mineralocorticoid receptor antagonist effect has been estimated at $60 \%$ of that of spironolactone. Due to a shorter duration of action, this drug should be administered more frequently than once daily (initially $25 \mathrm{mg}$ bid). However, eplerenone has not been licensed to treat PHA in the European Community.

\subsection{Catecholamine-producing tumours 8.6.1. Definition}

Adrenal catecholamine-producing tumours are known as phaeochromocytomas, and the remaining extra-adrenal chromaffin cell tumours, which may also be hormonally active, are known as paragangliomas. Collectively, these are called phaeochromocytomas-paragangliomas (PPGL).

It has been estimated that $80-85 \%$ of chromaffin cell tumours are located in the adrenal glands (phaeochromocytomas), and the remaining $15-20 \%$ are extra-adrenal.

\subsubsection{Clinical presentation}

Rich and variable clinical symptomatology of PPGL is related to the proportion of noradrenaline and adrenaline released by the tumour. Paroxysmal occurrence of symptoms which may have varying severity and recur with varying frequency is a characteristic feature. The provoking factors include exercise, abdominal pressure, large meals, some medications (ephedrine, phenylephrine, ACTH, phenothiazines, amphetamine, metoclopramide, tricyclic antidepressants, some anaesthesia drugs), stress, and alcohol intake. Catecholamine release by the tumour may also be induced by glucocorticosteroid administration. 


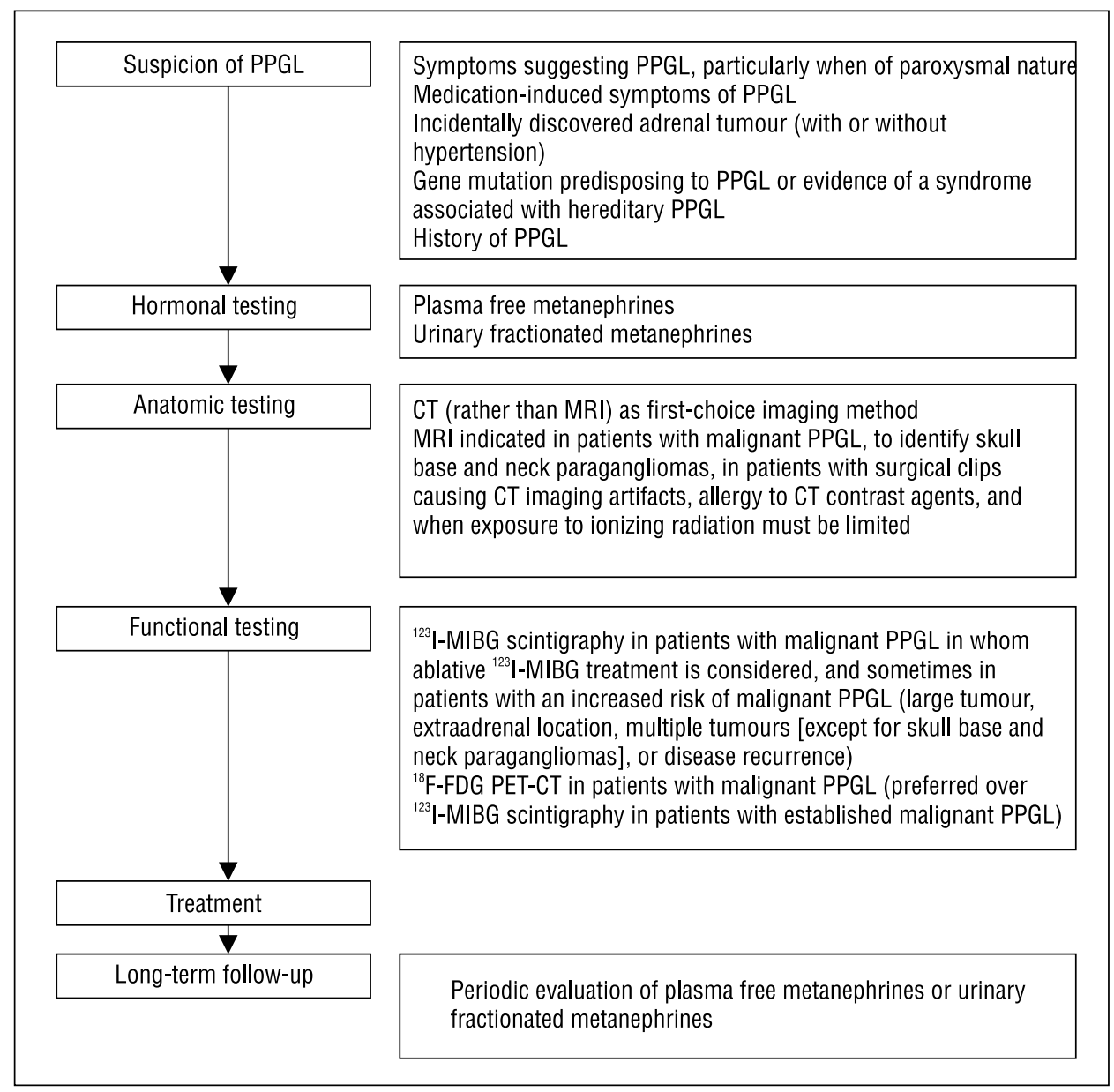

Figure 12. Diagnostic algorithm for phaeochromocytoma-paraganglioma

CT, computed tomography; FDG, fluorodeoxyglucose; MIBG, metaiodobenzylguanidine; MRI, magnetic resonance imaging; PET, positron emission tomography; PPGL, phaeochromocytoma-paraganglioma

Phaeochromocytomas may also remain asymptomatic (also with normal BP values).

The most common symptoms, usually paroxysmal in nature, include:

- paroxysmal BP surges (with typically large BP variation) which may last from several minutes to several hours;

- chronic hypertension;

- headache;

- excessive sweating;

- palpitation;

- pallor;

- tremor;

- anxiety;

- orthostatic hypotension.

On physical examination, skin may be pale and sweaty and pupils dilated, but most commonly, no characteristic PPGL signs are present. Elevated glucose level may be found on biochemical testing. ABPM may show large BP variation and a decreased nocturnal BP fall, or even a non-dipping BP pattern and $\mathrm{BP}$ elevation during the night.

\subsubsection{Investigations for phaeochromocytoma-pa- raganglioma}

The major diagnostic criterion for a hormonally active PPGL is the finding of an elevated urinary catecholamine metabolite excretion (or, less reliably, of catecholamines themselves) or their elevated serum level, with tumour localization by imaging studies. The final diagnosis is based on histopathologic assessment of the resected tumour. The diagnostic algorithm is summarized in Figure 12. The diagnosis of a hormonally non-functioning PPGL is based on imaging and functional studies, and the final diagnosis is again based on histopathologic assessment of the tumour.

Plasma free metanephrines and urinary fractionated metanephrines are considered the most useful (i.e., most sensitive) biochemical tests. The highest 
sensitivity was reported for plasma free metanephrines (sensitivity $97-99 \%$, specificity 82\%). Urinary adrenaline and noradrenaline excretion is characterized by lower sensitivity and specificity, and the least diagnostic utility was shown for measurements of urinary vanillylmandelic acid and dopamine and plasma catecholamines. In rare cases, the clonidine suppression test may be performed (with determination of plasma normetanephrine level before and at 3 hours after clonidine administration).

Anatomical imaging studies in patients with PPGL should be performed after excessive catecholamine metabolite levels have been identified in plasma or urine (Figure 12). Localization studies for PPGL are also performed in PPGL gene mutation carriers. Useful imaging methods for PPGL include $\mathrm{CT}$ and MRI.

\subsubsection{Management of phaeochromocytoma- -paraganglioma}

Paroxysmal BP surges caused by catecholamine -producing PPGL may be best managed by administering phentolamine intravenously, usually at the dose of 2-5 mg repeated as needed.

Surgical removal of catecholamine-producing PPGL is the treatment of choice.

Appropriate preoperative patient preparation is important to reduce BP values, lower the heart rate, and control paroxysmal BP surges and other symptoms related to the excess of circulating catecholamines. For this purpose, alpha-blockers are administered orally for 2-3 weeks, including phenoxybenzamine (in increasing doses starting from $10 \mathrm{mg}$ b.i.d. up to $1 \mathrm{mg} / \mathrm{kg} /$ day in $2-3$ divided doses) or doxazosin (in gradually increasing doses starting from $2 \mathrm{mg}$ up to $32 \mathrm{mg} /$ day in 1-2 divided doses). If alpha-adrenergic receptor blockade is unsuccessful at controlling BP, a calcium antagonist (nifedipine or amlodipine) may be added as the second antihypertensive medication. In patients with significant tachycardia, addition of a cardioselective beta-blocker is desirable but only after alpha-adrenergic receptors have been blocked. Catecholamines released by PPGL act on both alpha- and beta-adrenergic receptors. Administering a beta-blocker without previous alpha receptor blockade is contraindicated as it may lead to excessive alpha receptor activation and a significant $\mathrm{BP}$ rise. Drugs acting on both alpha- and beta-adrenergic receptors (labetalol and carvedilol) should not be used. Correcting hypovolemia by adequate sodium and fluid intake is also important during preoperative patient preparation to avoid orthostatic hypotension.

\subsubsection{Long-term care of patients with phaeochromocytoma-paraganglioma}

Following surgical removal of PPGL, long-term patient follow-up is needed that should include monitoring of $\mathrm{BP}$ values and plasma or urinary metanephrines. The initial postoperative evaluation to allow early identification of a possible tumour recurrence or development of hormonally active metastases should be undertaken depending on the overall clinical picture (genetic predisposition, tumour size, multiple tumours) after 6-12 months and then repeated annually.

\subsubsection{Genetic testing in patients with phaeochromocytoma-paraganglioma}

Each year, molecular biology advances in regard to the diagnosis of PPGL bring discoveries of new genes predisposing to this disease. In addition to 8 genes responsible for the most common hereditary PPGL syndromes (RET, VHL, NF1, SDHA, $S D H A F 2, S D H B, S D H C, S D H D$ ), new predisposing genes have also been identified, including $M E N 1$, MAX, TMEM127, EGLN1/PHD2, KIF1 $\beta$, IDH1, and HIF2 $\alpha$. The proportion of genetic forms of PPGL is currently estimated at 30-40\%. In addition, a founder $S D H D$ gene mutation has been identified in Poland. For this reason, genetic testing for known mutations associated with PPGL is recommended in all PPGL patients.

\subsubsection{Other rarer forms of secondary hypertension}

Other rarer forms of secondary hypertension, such as renin-secreting tumours, coarctation of the aorta, and Cushing syndrome, are summarized in Table XXV.

\section{Piśmiennictwo}

1. Adelman R.D., Coppo R., Dillon M.J. The emergency management of severe hypertension. Pediatr. Nephrol. 2000; 14: 422-427.

2. Aggoun Y., Sidi D., Bonnet D. Arterial dysfunction after treatment of coarctation of the aorta. Arch. Mal. Coeur Vaiss. 2001; 94: 785-789.

3. Alberti K.G., Zimmet P., Shaw J. IDF Epidemiology Task Force Consensus Group. The metabolic syndrome - a new worldwide definition. Lancet 2005; 366: 1059-1062.

4. ALLHAT Officers and Coordinators for the ALLHAT Collaborative Research Group. The Antihypertensive and Lipid Lowering Treatment to Prevent Heart Attack Trial. Major outcomes in moderately hypercholesterolemic, hypertensive patients randomized to pravastatin vs usual care: The Antihypertensive and Lipid-Lowering Treatment to Prevent Heart Attack Trial (ALLHAT-LLT). JAMA 2002; 288: 2998-3007.

5. Anderson W.P., Kett M.M., Stevenson A.J. i wsp. Renovascular hypertension. Structural changes in renal vasculature. Hypertension 2000; 36: 648-652. 
6. Antithrombotic Trialists' (ATT) Collaboration, Baigent C., Blackwell L., Collins R. i wsp. Aspirin in the primary and secondary prevention of vascular disease: collaborative meta-analysis of individual participant data from randomised trials. Lancet 2009; 373: 1849-1860.

7. Antoniewicz J., Litwin M., Pędich M. i wsp. Diagnosis and treatment of renovascular hypertension in children and adolescents - single center experience with 87 patients. J. Hypertens. 2007; 25 (supl. 2): S332.

8. Araki N., Umemura M., Miyagi Y. i wsp. Expression, transcription, and possible antagonistic interaction of the human Nedd4L gene variant: implications for essential hypertension. Hypertension 2008; 51: 773-777.

9. Atanasov A.G., Ignatova I.D., Nashev L.G. i wsp. Impaired protein stability of the 11 beta hydroxysteroid dehydrogenase type 2: a novel mechanism of apparent mineralocorticoid excess. J. Am. Soc. Nephrol. 2007; 18: 1262-1270.

10. Bakris G.L., Fonseca V., Katholi R.E. i wsp. GEMINI Investigators. Metabolic effects of carvedilol vs metoprolol in patients with type 2 diabetes mellitus and hypertension: a randomized controlled trial. JAMA 2004; 292: 2227-2236. 11. Baumgartner H., Bonhoeffer P., De Groot N.M. i wsp. Association for European Paediatric Cardiology (AEPC); ESC Committee for Practice Guidelines (CPG): ESC Guidelines for the management of grown-up congenital heart disease (new version 2010). Eur Heart J. 2010; 31: 2915-2957.

12. Beckett N.S., Peters R., Fletcher A.E. i wsp. HYVET Study Group. Treatment of hypertension in patients 80 years of age or older. N. Engl. J. Med. 2008; 358: 1887-1898.

13. Belch J., MacCuish A., Campbell I. i wsp. Prevention of Progression of Arterial Disease and Diabetes Study Group; Diabetes Registry Group; Royal College of Physicians Edinburgh. The prevention of progression of arterial disease and diabetes (POPADAD) trial: factorial randomised placebo controlled trial of aspirin and antioxidants in patients with diabetes and asymptomatic peripheral arterial disease. BMJ 2008; 337: a1840.

14. Bhat M.A., Neelakandhan K.S., Unnikrishnan M. i wsp. Fate of hypertension after repair of coarctation of the aorta in adults. Br. J. Surg. 2001; 88: 536-538.

15. Bilginturan N., Zilel i S., Karacadag S., Pirnar T. Hereditary brachydactyly associated with hypertension. Am. J. Med. Genet. 1973; 10: 253-259.

16. Bloch M.J., Basile J.N. Percutaneous revascularization of the renal arteries offers no evidence of clinical benefit in patients with atherosclerotic renal artery stenosis - the ASTRAL trial. J. Clin. Hypertens. (Greenwich) 2010; 12: 292-294.

17. Blood Pressure Lowering Treatment Trialists' Collaboration, Turnbull F., Neal B., Ninomiya T. i wsp. Effects of different regimens to lower blood pressure on major cardiovascular events in older and younger adults: metaanalysis of randomised trials. BMJ 2008; 336: 1121-1123.

18. Blumenthal J.A., Babyak M.A., Hinderliter A. i wsp. Effects of the DASH diet alone and in combination with exercise and weight loss on blood pressure and cardiovascular biomarkers in men and women with high blood pressure: the ENCORE study. Arch. Intern. Med. 2010; 170: 126-135.

19. Borghi C., Ambrosioni E., Novo S., Vinereanu D., Ambrosio G.; SMILE-4 Working Party. Comparison between zofenopril and ramipril in combination with acetylsalicylic acid in patients with left ventricular systolic dysfunction after acute myocardial infarction: results of a randomized, double-blind, parallel-group, multicenter, European study (SMILE-4). Clin. Cardiol. 2012; 35: 416-423.
20. Botero-Velez M., Curtis J.J., Warncock D.G. Liddle's syndrome revisited: a disorder of sodium reabsorption in the distal tubule. N. Engl. J. Med. 1994; 330: 178-181.

21. Brzezinska-Rajszys G., Quereshi S.A., Ksiazyk J. i wsp. Middle aortic syndrome treated with stent implantation. Heart 1999; 81: 166-170.

22. Buchi K.F., Siegler R.L. Hypertension in the first month of life. J. Hypertens. 1986; 4: 525-528.

23. Calhoun D.A., Jones D., Textor S. i wsp. Resistant hypertension: diagnosis, evaluation, and treatment: a scientific statement from the American Heart Association Professional Education Committee of the Council for High Blood Pressure Research. Hypertension 2008; 51: 1403-1419.

24. Celik T., Iyisoy A., Kursaklioglu H. i wsp. Comparative effects of nebivolol and metoprolol on oxidative stress, insulin resistance, plasma adiponectin and soluble P-selectin levels in hypertensive patients. J. Hypertens. 2006; 24: 591-596.

25. Constantine E., Linakis J. The assessment and management of hypertensive emergencies and urgencies in children. Pediatr. Emerg. Care 2005; 21: 391-396.

26. Cook N.R., Cutler J.A., Obarzank E. i wsp. Long term effects of dietary sodium reduction on cardiovascular disease outcomes: observational follow-up of the trials of hypertension prevention (TOHP). BMJ 2007; 334: 885-888.

27. Cosin J., Diez J. TORIC Investigators: Torasemide in chronic heart failure: results of the TORIC study. Eur. J. Heart Failure 2002; 4: 507-513.

28. Cushman W.C., Evans G.W., Byington R.P. i wsp.; ACCORD Study Group. Effects of intensive blood-pressure control in type 2 diabetes mellitus. N. Engl. J. Med. 2010; 362: 1575-1585.

29. Dahlof B., Devereux R.B., Kjeldsen S.E. i wsp.; LIFE Study Group: Cardiovascular morbidity and mortality in the Losartan Intervention For Endpoint reduction in hypertension study (LIFE): a randomised trial against atenolol. Lancet 2002; 359: 995-1003. 30. Dahlöf B., Sever P.S., Poulter N.R. i wsp.; ASCOT Investigators. Prevention of cardiovascular events with an antihypertensive regimen of amlodipine adding perindopril as required versus atenolol adding bendroflumethiazide as required, in the Anglo-Scandinavian Cardiac Outcomes Trial-Blood Pressure Lowering Arm (ASCOT-BPLA): a multicentre randomized controlled trial. Lancet 2005; 366: 895-906.

31. Daniels S.R. Repair of coarctation of the aorta and hypertension. Lancet 2001; 358: 89-91.

32. de Divitiis M., Pilla C., Kattenhorn M. i wsp. Ambulatory blood pressure, left ventricular mass, and conduit artery function late after successful repair of coarctation of the aorta. J. Am. Coll. Cardiol. 2003; 41: 2259-2265.

33. de Simone G., Daniels S.R., Deveraux R.B. i wsp. Left ventricular mass and body size in normotensive children and adults: assessment of allometric relations and impact of overweight. J. Am. Coll. Cardiol. 1992; 20: 1251-1260.

34. de Simone G., Deveraux R.B., Daniels S.R. i wsp. Effect of growth on variability of left ventricular mass: assessment of allometric signals in adults and children and their capacity to predict cardiovascular risk. J. Am. Coll. Cardiol. 1995; 25: 1056-1062.

35. de Swiet M., Fayers P., Shinebourne E.A. Blood pressure survey in a population of newborn infants. Br. Med. J. 1976; 2: 9-11.

36. de Swiet M., Fayers P., Shinebourne E.A. Systolic blood pressure in a population of infants in the first year of life: the Brompton study. Pediatrics 1980; 65: 1028-1035 
37. Dionne J.M., Abitbol C.L., Flynn J.T. Hypertension in infancy: diagnosis, management and outcome. Pediatr. Nephrol. 2012; 27: 17-32.

38. Dodson P.M., Lip G.Y., Eames S.M. i wsp. Hypertensive retinopathy: a review of existing classification systems and a suggestion for a simplified grading system. J. Hum. Hypertens. 1996; 10: 93-98.

39. Doyon A., Kracht D., Bayazit A.K. i wsp. Carotid artery intima-media thickness and distensibility in children and adolescents: reference values and role of body dimensions. Hypertension 2013; 62: 550-556.

40. ESCAPE Trial Group, Wühl E., Trivelli A., Picca S. i wsp. Strict blood-pressure control and progression of renal failure in children. N. Engl. J. Med. 2009; 361: 1639-1650.

41. Feig D.I., Johnson R.J. The role of uric acid in pediatric hypertension. J. Ren. Nutr. 2007; 17: 79-83.

42. Feldman R.D., Zou G.Y., Vandervoort M.K., Wong C.J., Nelson S.A., Feagan B.G. A simplified approach to the treatment of uncomplicated hypertension: a cluster randomized, controlled trial. Hypertension 2009; 53: 598-999.

43. Fischer D.C., Schreiver C., Heimhalt M. i wsp. Pediatric reference values of carotid-femoral pulse wave velocity determined with an oscillometric device. J. Hypertens. 2012; 30: 2159-2167.

44. Flynn J.T. Neonatal hypertension: diagnosis and management. Pediatr. Nephrol. 2000; 14: 332-341.

45. Flynn J.T., Alderman M.H. Characteristics of children with primary hypertension seen at a referral center. Pediatr. Nephrol. 2005; 20: 961-966.

46. Flynn J.T., Daniels S.R. Pharmacologic treatment of hypertension in children and adolescents. J. Pediatr. 2006; 149: 746. 47. Flynn J.T., Daniels S.R., Hayman L.L. i wsp. American Heart Association Atherosclerosis, Hypertension and Obesity in Youth Committee of the Council on Cardiovascular Disease in the Young: Update: ambulatory blood pressure monitoring in children and adolescents: a scientific statement from the American Heart Association. Hypertension 2014; 63: 1116-1135.

48. Flynn J.T., Tullus K. Severe hypertension in children. Pediatr. Nephrol. 2009; 24: 1101-1112.

49. Funder J.W., Carey R.M., Fardella C. i wsp. Case detection, diagnosis, and treatment of patients with primary aldosteronism: an endocrine society clinical practice guideline. J. Clin. Endocrinol. Metab. 2008; 93: 3266-3281.

50. Funder J.W., Carey R.M., Fardella C. i wsp. Case detection, diagnosis, and treatment of patients with primary aldosteronism: an endocrine society clinical practice guideline. J. Clin. Endocrinol. Metab. 2008; 93: 3266-3281.

51. Goldstein D.S., Eisenhower G., Flynn J.A. i wsp. Diagnosis and localization of pheochromocytoma. Hypertension 2004; 43: 907-910.

52. Grupa Robocza Polskiego Towarzystwa Nadciśnienia Tętniczego. Wytyczne dotyczące diagnostyki i leczenia chorych z guzem chromochłonnym. Nadciśnienie Tętnicze 2006; 10: 1-19. 53. Grupa Robocza Polskiego Towarzystwa Nadciśnienia Tętniczego. Zalecenia dotyczące diagnostyki i leczenia pierwotnego hiperaldosteronizmu. Nadciśnienie Tętnicze 2008; 12: $155-168$.

54. Gupta-Malhotra M., Banker A., Shete S. i wsp: Essential hypertension vs. secondary hypertension among children. Am. J. Hypertens. 2015; 28: 73-80.

55. Hadtstein C., Schaefer F. Hypertension in children with chronic kidney disease: pathophysiology and management. Pediatr. Nephrol. 2008; 23: 363-371.
56. Haller H., Ito S., Izzo J.L. Jr i wsp.; ROADMAP Trial Investigators: Olmesartan for the delay or prevention of microalbuminuria in type 2 diabetes. N. Engl. J. Med. 2011; 364: 907-917.

57. Hansson L., Zanchetti A., Carruthers S.G. i wsp. Effect of intensive blood pressure lowering and low-dose aspirin in patients with hypertension: principal results of the Hypertension Optimal Treatment (HOT) randomised trial. Lancet 1998; 351: 1755-1762.

58. Havekes B., Romijn J.A., Eisenhofer G. i wsp. Update on pediatric phaeochromocytoma. Pediatr. Nephrol. 2009; 24: 943-950.

59. http://www.dableducational.org.

60. Jamerson K., Weber M.A., Bakris G.L. i wsp. ACCOMPLISH Trial Investigators. Benazepril plus amlodipine or hydrochlorothiazide for hypertension in high-risk patients. N. Engl. J. Med. 2008; 359: 2417-2428.

61. Jourdan C., Wuhl E., Litwin M. i wsp. Normative values of intima-media thickness and distensibility of large arteries in healthy adolescents. J Hypertens. 2005; 23: 1707-1715.

62. Kaiser T., Heise T., Nosek L. i wsp. Influence of nebivolol and enalapril on metabolic parameters and arterial stiffness in hypertensive type 2 diabetic patients. J. Hypertens. 2006; 24: 1397-1403.

63. Kandzari D.E., Bhatt D.L., Sobotka P.A. i wsp. Catheter-based renal denervation for resistant hypertension: rationale and design of the SYMPLICITY HTN-3 Trial. Clin. Cardiol. 2012; 35: 528-535.

64. Kent A.L., Kecskes Z., Shadbolt B., Falk M.C. Blood pressure in the first year of life in healthy infants born at term. Pediatr. Nephrol. 2007; 22: 1743-1749.

65. Kent A.L., Kecskes Z., Shadbolt B., Falk M.C. Normative blood pressure data in the early neonatal period. Pediatr. Nephrol. 2007; 22: 1335-1341.

66. Kent A.L., Meskell S., Falk M.C. Normative blood pressure data in non-ventilated premature neonates from 28-36 weeks gestation. Pediatr. Nephrol. 2009; 24: 141-146.

67. Khoury P.R., Mitsnefes M., Daniels S.R. i wsp. Agespecific reference intervals for indexed left ventricular mass in children. J. Am. Soc. Echocardiogr. 2009; 22: 709-714.

68. Kułaga Z., Litwin M., Grajda A. i wsp.; OLAF Study Group. Oscillometric blood pressure percentiles for Polish normal weight school-aged children and adolescents. J. Hypertens. 2012; 30: 1942-1954.

69. Kułaga Z., Litwin M., Zajączkowska M.M. i wsp. Comparison of waist and hip circumferences ranges in children and adolescents in Poland 7-18 y of age with cardiovascular risk thresholds - initial results of OLAF project (PL0080). Standardy Medyczne 2008; 5: 473-485.

70. Lande M.B., Flynn J.T. Treatment of hypertension in children and adolescents. Pediatr. Nephrol. 2009; 24: 1939-1949. 71. Lenders J.W., Duh Q.Y., Eisenhofer G. i wsp. Pheochromocytoma and paraganglioma: an endocrine society clinical practice guideline. J. Clin. Endocrinol. Metab. 2014; 99: 1915-1942. 72. Lenders J.W., Duh Q.Y., Eisenhofer G. i wsp. Pheochromocytoma and paraganglioma: an endocrine society clinical practice guideline. J. Clin. Endocrinol. Metab. 2014; 99: 1915-1942. 73. Li A., Tedde R., Krozowski Z.S. i wsp. Molecular basis for hypertension in the "type II" variant of apparent mineralocorticoid excess. Am. J. Hum. Genet. 1998; 63: 370-379.

74. Lindheimer M.D., Taler S.J., Cunningham F.G. Hypertension in pregnancy. J. Am. Soc. Hypertens. 2008; 2: 484-494. 
75. Litwin M. Diagnostyka nadciśnienia tętniczego u dzieci. W: Więcek A. Hipertensjologia. Medycyna Praktyczna 2010. 76. Litwin M. Leczenie nadciśnienia tętniczego u młodzieży. W: Litwin M., Prejbisz A., Januszewicz A. Nadciśnienie tętnicze u młodzieży i młodych dorosłych. Medycyna Praktyczna 2011. 77. Litwin M. Risk factors for renal failure progression in children. Pediatr. Nephrol. 2004; 19: 178-186.

78. Litwin M., Grenda R., Sladowska J., Antoniewicz J. Add-on therapy with angiotensin II receptor 1 blocker in children with chronic kidney disease already treated with angiotensin-converting enzyme inhibitors. Pediatr. Nephrol. 2006; 21: 1716-1722. 79. Litwin M., Michałkiewicz J., Gackowska L. Primary hypertension in children and adolescents is an immuno-metabolic disease with hemodynamic consequences. Curr. Hypertens. Rep. 2013; 15: 331-339.

80. Litwin M., Niemirska A. Intima-media thickness measurements in children with cardiovascular risk factors. Pediatr. Nephrol. 2009; 24: 707-719.

81. Litwin M., Niemirska A., Śladowska J. i wsp. Left ventricular hypertrophy and arterial wall thickening in children with essential hypertension. Pediatr. Nephrol. 2006; 21: 811-819. 82. Litwin M., Śladowska J., Antoniewicz J. i wsp. Metabolic abnormalities, insulin resistance, and metabolic syndrome in children with primary hypertension. Am. J. Hypertens. 2007; 20: 875-882.

83. Litwin M., Sladowska-Kozlowska K. Diagnostyka różnicowa nadciśnienia tętniczego u młodzieży. W: Litwin M., Prejbisz A., Januszewicz A. Nadciśnienie tętnicze u młodzieży i młodych dorosłych. Medycyna Praktyczna 2011.

84. Lurbe E., Cifkova R., Cruikshank J.K. i wsp. Management of high blood pressure in children and adolescents: Recommendations of the European Society of Hypertension. J. Hypertens. 2009; 27: 1719-1742.

85. Mancia G., De Backer G., Dominiczak A. i wsp. Management of Arterial Hypertension of the European Society of Hypertension/European Society of Cardiology. 2007 Guidelines for the Management of Arterial Hypertension: The Task Force for the Management of Arterial Hypertension of the European Society of Hypertension (ESH) and of the European Society of Cardiology (ESC). J. Hypertens. 2007; 25: 1105-1187.

86. Mancia G., Fagard R., Narkiewicz K. i wsp. 2013 ESH/ /ESC Guidelines for the management of arterial hypertension. J. Hypertens. 2013; 31: 1281-1357.

87. Mancia G., Laurentb S., Agabiti-Rosei E. i wsp. Reappraisal of European guidelines on hypertension management: a European Society of Hypertension Task Force document. J. Hypertens. 2009; 27: 2121-2158.

88. McCambridge T.M., Benjamin H.J., Brenner J.S. i wsp.; Council on Sports Medicine and Fitness: Policy Statement. Athletic participation by children and adolescents who have systemic hypertension. Pediatrics 2010; 125: 1287-1294.

89. Monticone S., Viola A., Rossato D. i wsp. Adrenal vein sampling in primary aldosteronism: towards a standardised protocol. Lancet Diabetes Endocrinol. 2015; 3: 296-303.

90. Monticone S., Viola A., Rossato D. i wsp. Adrenal vein sampling in primary aldosteronism: towards a standardised protocol. Lancet Diabetes Endocrinol. 2014; 3: 296-303.

91. Nagueh S.F., Appleton C.P., Gillebert T.C. i wsp. Recommendations for the evaluation of left ventricular diastolic function by echocardiography. J. Am. Soc. Echocardiogr. 2009; 22: $107-133$.

92. National High Blood Pressure Education Program Working Group on High Blood pressure in children and adolescents: The fourth Report on diagnosis, evaluation and treatment of high blood pressure in children and adolescents. Pediatrics 2004; 114: 555-576.

93. NAVIGATOR Study Group. Effect of valsartan on the incidence of diabetes and cardiovascular events. N. Engl. J. Med. 2010; 362: 1477-1490.

94. Nwankwo M.A., John M., Lorenz J.C. i wsp. Standard protocol for blood pressure measurement in the Newborn. Pediatrics 1997; 99: e10.

95. O’Brien E., Mee F., Atkins N., O’Malley K. Short report: Accuracy of the Dinamap portable monitor, model 8100 determined by the British Hypertension Society protocol. J. Hypertens. 1993; 11: 761-763.

96. O'Brien E., Mee F., Atkins N., Thomas M. Evaluation of three devices for self-measurement of blood pressure according to the revised British Hypertension Protocol: the Omron HEM -705CP, Phillips HP5332, and Nissei DS-175. Blood Press. Monit. 1996; 1: 55-61.

97. O'Sullivan J.J., Derrick G., Darnell R. Prevalence of hypertension in children after early repair of coarctation of the aorta: a cohort study using casual and 24 hour blood pressure measurement. Heart 2002; 88: 163-166.

98. ONTARGET Investigators, Yusuf S., Teo K.K., Pogue J. i wsp. Telmisartan, ramipril, or both in patients at high risk for vascular events. N. Engl. J. Med. 2008; 358: 1547-1559. 99. Padwal R.J., Hemmelgaru B.R., Khan N.A. i wsp. The 2008 Canadian Hypertension Education Program recommendations for the management of hypertension. Can. J. Cardiol. 2008; 24: 455-475.

100. Parati G., Lombardi C., Hedner J. i wsp. Position paper on the management of patients with obstructive sleep apnea and hypertension: joint recommendations by the European Society of Hypertension, by the European Respiratory Society and by the members of European COST (COoperation in Scientific and Technological research) ACTION B26 on obstructive sleep apnea. J. Hypertens. 2012; 30: 633-646.

101. Parati G., Stergiou G.S., Asmar R. i wsp. European Society of Hypertension guidelines for blood pressure monitoring at home: a summary report of the Second International Consensus Conference on Home Blood Pressure Monitoring. J. Hypertens. 2008; 26: 1505-1530.

102. Park M.K., Menard S.W., Yuan C. Comparison of auscultatory and oscillometric blood pressures. Arch. Pediatr. Adolesc. Med. 2001; 55: 50-53.

103. Parving H.H., Brenner B.M., McMurray J.J.V. i wsp.; for the ALTITUDE Investigators. Cardiorenal end points in a trial of aliskiren for type 2 diabetes. N. Engl. J. Med. 2012; 367: 2204-2213.

104. Patel A.; ADVANCE Collaborative Group, MacMahon S., Chalmers J., Neal B. i wsp. Effects of a fixed combination of perindopril and indapamide on macrovascular and microvascular outcomes in patients with type 2 diabetes mellitus (the ADVANCE trial): a randomised controlled trial. Lancet 2007; 370: 829-840.

105. PATS Collaborating Group. Post-stroke antihypertensive treatment study. A preliminary result. Chin. Med. J. (Engl.) 1995; 108: 710-717.

106. Pęczkowska M., Januszewicz A., Jarząb B. i wsp. Pheochromocytoma in children and adolescents based on Polish Pheochromocytoma Registry. Ann. Diag. Paed. Pathol. 2007; 11: 15-19.

107. Pepine C.J., Handberg E.M., Cooper-DeHoff R.M. i wsp.; INVEST Investigators. A calcium antagonist vs a noncalcium 
antagonist hypertension treatment strategy for patients with coronary artery disease. The International Verapamil-Trandolapril Study (INVEST): a randomized controlled trial. JAMA 2003; 290: 2805-2816.

108. Perk J., De Backer G., Gohlke H. i wsp. European Guidelines on cardiovascular disease prevention in clinical practice (version 2012): The Fifth Joint Task Force of the European Society of Cardiology and Other Societies on Cardiovascular Disease Prevention in Clinical Practice (constituted by representatives of nine societies and by invited experts). Eur. Heart J. 2012; 33: 1635-1701.

109. Persu A., Giavarini A., Touze E. i wsp. European consensus on the diagnosis and management of fibromuscular dysplasia. J. Hypertens. 2014; 32: 1367-1378.

110. Peterson A.L., Frommelt P.C., Mussatto K. Presentation and echocardiographic markers of neonatal hypertensive cardiomyopathy. Pediatrics 2006, 118: 782-785.

111. Pływaczewski R., Brzecka A., Bielicki P. i wsp. Zalecenia Polskiego Towarzystwa Chorób Płuc dotyczące rozpoznawania i leczenia zaburzeń oddychania w czasie snu (ZOCS) u dorosłych. Pneumonologia i Alergologia Polska 2013; 81: 221-258. 112. Qaseem A., Holty J.E., Owens D.K. i wsp. Management of obstructive sleep apnea in adults: a clinical practice guideline from the American College of Physicians. Ann. Intern. Med. 2013; doi: 10.7326/0003-4819-159-7-201310010-00704. [Epub ahead of print].

113. Report of the Second Task Force on Blood Pressure Control in Children - 1987. Task Force on Blood Pressure Control in Children. National Heart, Lung, and Blood Institute, Bethesda, Maryland. Pediatrics 1987; 79: 1-25.

114. Reusz S., Cseprekal O., Temmar M. Reference values of pulse wave velocity in healthy children and teenagers. Hypertension 2010; 56: 217-224.

115. Ridker P.M., Danielson E., Fonseca F.A. i wsp.; for the JUPITER Study Group. Rosuvastatin to prevent vascular events in men and women with elevated C-reactive protein. N. Engl. J. Med. 2008; 359: 2195-2207.

116. Rossi G.P., Auchus R.J., Brown M. i wsp. An expert consensus statement on use of adrenal vein sampling for the subtyping of primary aldosteronism. Hypertension 2014; 63: 151-160.

117. Rozporządzenie Ministra Zdrowia z dnia 29 sierpnia 2009 r. w sprawie świadczeń gwarantowanych z zakresu podstawowej opieki zdrowotnej Dz. U. 2009.139.1139.

118. Schrader J., Luders S., Kulschewski A. i wsp.; MOSES Study Group. Morbidity and mortality after stroke, eprosartan compared with nitrendipine for secondary prevention: principal results of a prospective randomized controlled study (MOSES). Stroke 2005; 36: 1218-1226.

119. Schroff R., Roebuck D.J., Gordon I. i wsp. Angioplasty for renovascular hypertension in children: 20 year experience. Pediatrics 2006; 118: 268-275.

120. Singh H.P., Hurley R.M., Myers T.F. Neonatal hypertension: incidence and risk factors. Am. J. Hypertens. 1992; 5: $51-55$.

121. Skalina M.E.L., Kliegman R.M., Fanaroff A.A. Epidemiology and management of severe symptomatic neonatal hypertension. Am. J. Perinatol. 1986; 3: 235-239.

122. Sladowska J., Niemirska A., Litwin M., Grenda R. Nadciśnienie tętnicze u dzieci. Część 1: Zasady postępowania diagnostycznego. Standardy Med. 2005; 2: 1452-1462.

123. Slovut D.P., Olin J.W. Fibromuscular dysplasia. N. Engl. J. Med. 2004; 350: 1862-1871.
124. Soejima H., Morimoto T., Saito Y. i wsp. Aspirin for the primary prevention of cardiovascular events in patients with peripheral artery disease or diabetes mellitus. Analyses from the JPAD, POPADAD and AAA trials. Thromb. Haemost. 2010; 104: 1085-1088.

125. Staessen J.A., Thijis L., Fagard R. i wsp.; Systolic Hypertension in Europe (Syst-Eur) Trial Investigators. Effects of immediate versus delayed antihypertensive therapy on outcome in the Systolic Hypertension in Europe Trial. J. Hypertens. 2004; 22: 847-857.

126. Stanowisko grupy ekspertów dotyczące diagnostyki obrazowej i wskazań do wykonywania zabiegów przezskórnej angioplastyki zwężenia tętnicy nerkowej u chorych z NT. Przyjęte przez Polskie Towarzystwo Nadciśnienia Tętniczego, Polskie Towarzystwo Nefrologiczne i Polskie Towarzystwo Kardiologiczne. Kardiologia Polska 2010; 68: 860-867.

127. Stanowisko PTNT. Stosowanie produktów o ograniczonej zawartości sodu. Nadciśnienie Tętnicze 2007; 11: 84.

128. Stergiou G.S., Christodoulakis G., Giovas P. i wsp. Home blood pressure monitoring in children. How many measurements are needed? Am. J. Hypertens. 2008; 21: 633-638.

129. Stewart P. Dexamethasone-suppressible aldosteronism. Lancet 2000; 356: 697-698.

130. Symonides B., Jędrusik P., Artyszuk L. i wsp. Different diagnostic criteria significantly affect the rates of hypertension in 18-year-old high school students. Arch. Med. Sci. 2010; 6: 689-694.

131. Symplicity HTN-1 Investigators. Catheter-based renal sympathetic denervation for resistant hypertension durability of blood pressure reduction out to 24 months. Hypertension 2011; 57: 911-917.

132. Symplicity HTN-2 Investigators, Esler M.D., Krum H., Sobotka P.A., Schlaich M.P., Schmieder R.E., Böhm M. Renal sympathetic denervation in patients with treatment-resistant hypertension (The Symplicity HTN-2 Trial): a randomised controlled trial. Lancet 2010; 376: 1903-1909.

133. Telmisartan Randomised AssessmeNt Study in ACE iNtolerant subjects with cardiovascular Disease (TRANSCEND) Investigators, Yusuf S., Teo K., Anderson C. i wsp. Effects of the angiotensin-receptor blocker telmisartan on cardiovascular events in high-risk patients intolerant to angiotensin-converting enzyme inhibitors: a randomized controlled trial. Lancet 2008; 372: 1174-1183.

134. Tendera M., Aboyans V., Bartelink M.L. i wsp. ESC Guidelines on the diagnosis and treatment of peripheral artery diseases: Document covering atherosclerotic disease of extracranial carotid and vertebral, mesenteric, renal, upper and lower extremity arteries: the Task Force on the Diagnosis and Treatment of Peripheral Artery Diseases of the European Society of Cardiology (ESC). Eur. Heart J. 2011; 32: 2851-2906.

135. Toka O., Maas P.G., Aydin A. i wsp. Childhood hypertension in autosomal-dominant hypertension with brachydactyly. Hypertension 2010; 56: 988-994.

136. Turnbull F., Woodward M., Neal B. i wsp.; Blood Pressure Lowering Treatment Trialists' Collaboration. Do men and women respond differently to blood pressure-lowering treatment? Results of prospectively designed overviews of randomized trials. Eur. Heart J. 2008; 29: 2669-2680.

137. Urbina E., Alpert B., Flynn J. i wsp.; American Heart Association Atherosclerosis, Hypertension, and Obesity in Youth Committee. Ambulatory blood pressure monitoring in children and adolescents: recommendations for standard assessment: 
a scientific statement from the American Heart Association Atherosclerosis, Hypertension and Obesity in Youth Committee of the Council on Cardiovascular Disease in the Young and the Council for High Blood Pressure Research. Hypertension 2008; 52: 433-451.

138. Van Bortel L.M., Laurent S., Boutouyrie P. i wsp.; Artery Society; European Society of Hypertension Working Group on Vascular Structure and Function; European Network for Noninvasive Investigation of Large Arteries. Expert consensus document on the measurement of aortic stiffness in daily practice using carotid-femoral pulse wave velocity. J. Hypertens. 2012; 30: 445-448.

139. Vehaskari V.M. The heritable forms of hypertension. Pediatr. Nephrol. 2009; 24: 1929-1937.

140. Verdecchia P., Staessen J.A., Angeli F. i wsp. Usual versus tight control of systolic blood pressure in non-diabetic patients with hypertension (Cardio-Sis): an open-label randomised trial. Lancet 2009; 374: 525-533.

141. Waguespack S.G., Rich T., Grubbs E. i wsp. A current review of the etiology, diagnosis and treatment of pediatric phaeochromocytoma and paraganglioma. J. Clin. Endocrinol. Metab. 2010; 95: 2023-2037.

142. Watkinson M. Hypertension in the newborn baby. Arch. Dis. Child. Fetal Neonatal Ed. 2002; 86: F78-F81.

143. Weber M.A., Julius S., Kjeldsen S.E. i wsp. Blood pressure dependent and independent effects of antihypertensive treatment on clinical events in the VALUE Trial. Lancet 2004; 363: 2049-2051.

144. Witkowski A., Januszewicz A., Imiela J. i wsp. Stanowisko grupy ekspertów w sprawie zabiegów przezskórnej denerwacji nerek w leczeniu nadciśnienia tętniczego w Polsce. Kardiol. Pol. 2011; 69: 1208-1211.
145. Witkowski A., Prejbisz A., Florczak E. i wsp. Effects of renal sympathetic denervation on blood pressure, sleep apnea course, and glycemic control in patients with resistant hypertension and sleep apnea. Hypertension 2011; 58: 559-565.

146. Wong T.Y., Mitchell P. Hypertensive retinopathy. N. Engl. J. Med. 2004; 351: 2310-2317.

147. Wühl E., Witte K., Soergel M., Mehls O., Schaefer F.; German Working Group on Pediatric Hypertension: Distribution of 24-h ambulatory blood pressure in children: normalized reference values and role of body dimensions. J. Hypertens. 2002; 20: 1995-2007.

148. Yusuf S., Diener H.C., Sacco R.L. i wsp. PRoFESS Study Group. Telmisartan to prevent recurrent stroke and cardiovascular events. N. Engl. J. Med. 2008; 359: 1225-1237.

149. Yusuf S., Sleight P., Pogue J., Bosch J., Davies R., Dagenais $\mathrm{G}$. Effects of an angiotensin-converting-enzyme inhibitor, ramipril, on cardiovascular events in high-risk patients. The Heart Outcomes Prevention Evaluation Study Investigators. N. Engl. J. Med. 2002; 342: 145-153.

150. Zasady postępowania w nadciśnieniu tętniczym -2011 rok. Wytyczne Polskiego Towarzystwa Nadciśnienia Tętniczego. Nadciśnienie Tętnicze 2011; 15: 55-82.

151. Zasady postępowania w nadciśnieniu tętniczym. Wytyczne Polskiego Towarzystwa Nadciśnienia Tętniczego oraz Kolegium Lekarzy Rodzinnych w Polsce. Nadciśnienie Tętnicze 2008; 12: 317-342. 152. Zimmet P., Alberti K., George M.M. i wsp. The metabolic syndrome in children and adolescents - an IDF consensus report. Pediatr. Diabetes 2007; 8: 299-306.

153. Zubrow A.B., Hulman S., Kushner H., Falkner B. Determinants of blood pressure in infants admitted to neonatal intensive care units: a prospective multicenter study. J. Perinatol. 1999; 15: 470-479. 